Journal of Integrative and Anatolian Medicine

Bütünleyici ve Anadolu Tıbbı Dergisi
Cilt/ Volume: 2 Sayı / Issue: 3

Yll/Year: 2021
Yayınc1 / Publisher Sağlk Bilimleri Üniversitesi University of Health Sciences

\title{
The Assessment of Complementary and Alternative Medicine Use Among Patients with Hematological Malignancies
}

\author{
Hakan KESKİ ID \\ University of Health Sciences Turkey, İstanbul Ümraniye Training and Research Hospital, \\ Department of Hematology, Ümraniye, İstanbul, Turkey \\ *Sorumlu Yazar / Corresponding Author: Hakan KESKİ, e-mail: keski1976@gmail.com
}

\section{ÖZET}

Complementary and alternative medicine (CAM) is increasingly used among oncology patients. In the literature, the studies on hematological malignancy (HM) patients' use of CAM are scarce. We aimed to assess CAM use in a group of Turkish HM patients by a multi-parameter approach and determine the demographic and clinical factors associated with its use. This descriptive and cross-sectional study was conducted in the outpatient clinics with 351 eligible patients. Two questionnaires, one of which assessed the attitudes of participants to CAM (HCAMQ), and the other detailed multiple aspects of CAM use were applied. The frequency of CAM use was $70.1 \%$ and, among the most common CAM methods, were phytotherapy (65\%), vitamin supplementation, and spiritual activity/prayer. The statistical analysis results showed that the rate of CAM use was significantly associated with lower ECOG performances (p:0.016) and lower HCAMQ scores $(\mathrm{p}<0.001)$. The use of Ozone therapy was significantly associated with older age (p:0.042) and higher ECOG performance score (p:0.038) while hijama use was significantly more in the graduates of elementary school (p:0.033), and in the patients who did not undergo chemotherapy ( $<0.001)$ and who had high-risk/malignant conditions $(p<0.001)$. We found that apitherapy and leech therapy uses were significantly associated with high-risk/malignant conditions (p:0.011 and p:0.004, respectively). Social media was found as the primary source of information for phytotherapy (p:0.016), Nigella sativa (p:0.007), and Gingko biloba (p:0.026) while TV/newspaper was so for Curcuma longa (p:0.018). We found a high frequency of CAM use among HM patients, and we expect that our comprehensive research will contribute to the literature and set an example for further and larger studies.

Key words: Complementary and alternative medicine, Hematologic malignancies, Phytotherapy, Curcuma longa, Urtica dioica 


\title{
Hematolojik Maligniteli Hastalar Arasında Tamamlayıcı ve Alternatif Tıp Kullanımının Değerlendirilmesi
}

\begin{abstract}
Tamamlayıcı ve alternatif tıp (TAT) onkoloji hastaları arasında giderek daha fazla kullanılmaktadır. Literatürde, hematolojik malignite (HM) hastalarının TAT kullanımı ile ilgili çalışmaların oranı azdır. Bir grup Türk HM hastasında, TAT kullanımını çok parametreli bir yaklaşımla değerlendirmeyi ve kullanımı ile ilişkili demografik ve klinik faktörleri belirlemeyi amaçladık. Gerekli nitelikleri taşıyan 351 hastanın katılımı ile ayakta tedavi polikliniklerinde tanımlayıcı ve kesitsel bir çalışma gerçekleştirildi. Hastalara katılımcıların TAT'a (HCAMQ) karşı tutumlarını ve ayrıntılı TAT kullanımının birçok yönünü değerlendiren iki anket uyguland. TAT kullanım sıklığ $1 \% 70.1$ idi ve en yaygın TAT yöntemleri arasında fitoterapi (\%65), vitamin takviyesi ve ruhsal aktivite/dua yer almaktaydı. İstatistiksel analiz sonuçları, TAT kullanım oranının anlamlı olarak düşük ECOG performansları $(p=0,016)$ ve düşük HCAMQ skorları $(p$ $<0,001)$ ile ilişkili olduğunu gösterdi. Ozon tedavisi kullanımı ileri yaş $(p=0,042)$ ve yüksek ECOG performans skoru $(\mathrm{p}=0,038)$ ile anlamlı olarak ilişkili idi. Hacamat kullanımı ilkokul mezunlarında $(p=0,033)$, kemoterapi almayanlarda $(p<0,001)$ ve yüksek riskli maligniteli hastalarda $(p<0,001)$ anlamlı olarak daha fazlaydı. Apiterapi ve sülük tedavisi kullanımlarının yüksek riskli malignite durumları ile anlamlı olarak ilişkili olduğunu bulduk (sırasıyla $\mathrm{p}=0,011$ ve $\mathrm{p}=0,004$ ). Sosyal medyanın fitoterapi $(\mathrm{p}=0.016)$, Nigella sativa $(\mathrm{p}=0.007)$ ve Gingko biloba $(\mathrm{p}=0.026)$ ve TV / gazetenin Curcuma longa için $(\mathrm{p}=0.018)$ birincil bilgi kaynağı olduğu bulundu. HM hastalarında TAT kullanımının yüksek sıklıkta olduğunu bulduk ve bizim kapsamlı araştırmamızın literatüre katkıda bulunacağını ve daha ileri ve daha büyük çalışmalara örnek olacağını bekliyoruz.
\end{abstract}

Anahtar kelimeler: Tamamlayıcı ve alternatif tıp, hematolojik maligniteler, fitoterapi, Curcuma longa, Urtica dioica

\section{INTRODUCTION}

Hematologic malignancies (HM), which comprised $6.5 \%$ of new cancer cases worldwide and had a $7.2 \%$ mortality rate in 2018 , are a spectrum of hematopoiesis disorders that originate from bone marrow or lymph nodes (Bray et al., 2018). In addition to the conventional medical management with chemotherapy and radiotherapy, recent advances such as immunotherapy and stem cell transplantation present promising treatment options with better survival rates. Nevertheless, the adverse reactions related to or resistance to therapy continue to challenge patients' quality of life and lead them to symptom-controlling solutions and comfort- seeking behaviors (Okolo \& Gowin, 2019). Therefore, many cancer survivors turn to unorthodox approaches and start experimenting some sort of complementary and alternative medicine (CAM), which can simply be defined as the broad range of interventional practices beyond the scope of standard medical care strategies. Although there is still an ongoing debate about the frequency of use as well as the definition, classification, efficacy, adverse effects, extent and limits of various CAM methods used all around the world, the global report of WHO has demonstrated that $88 \%$ of member states relays the national use of CAM (WHO, 2019). Moreover, the emerging 
Cilt/ Volume: 2 Sayı / Issue: 3

Yil/Year: 2021
Yayıncı / Publisher

Sağllk Bilimleri Üniversitesi University of Health Sciences regulatory guidelines have revealed the recognition of CAM by prestigious health organizations. In Turkey, the Ministry of Health regulated the use of CAM in 2014 and officially addressed the educational prerequisites and qualifications of the health personnel to be licensed for practicing CAM, and the spectrum of CAM methods allowed to be used in the country (Yönetmelik, 2014).

As a consequence of recent developments, it has become justifiable to place the oncologyrelated CAM applications under the umbrella of Integrative Oncology, which was described as "patient-centered, evidence-informed field of cancer care that utilizes mind and body practices, natural products, and/or lifestyle modifications from different traditions alongside conventional cancer treatments" by the Society of Integrative Oncology (Witt et al., 2017). The reasons for the oncology patients' use of CAM range from boosting the quality of life to coping with the therapeutic side effects in addition to enhancing psychological and physical well-being. The practices of CAM vary among populations and greatly depend on the socio-economic, cultural, and geographical structure (Hakkoymaz \& Koçyiğit, 2019). There are literature data indicating the demographic features such as age, gender, education, and the clinical characteristics, like the diagnosis, treatment, and comorbidities are the main influencers of CAM use and related patterns, such as the source of information of, the attitudes towards, and the perceived effects from CAM (Abuelgasim et al., 2018; Bauml et al., 2015; Berretta et al., 2017; Can, Erol, Aydiner, \& Topuz, 2009; D'Arena et al., 2014; Demir \& Erol, 2018; Gan, Leong, Bee, Chin, \& Teh, 2015; Gözüm, Tezel, \& Koc, 2003; Hakkoymaz \& Koçyiğit, 2019; Hensel, Zoz, \& Ho, 2009; Hierl et al., 2017; Karacan et al., 2012; Lopez et al., 2019; Molassiotis et al., 2005; Rausch Osian et al., 2015; Risberg et al., 2003; Tas et al., 2005; Tazi, Nafil, Sifesalam, Bouchtia, \& Mahmal, 2013; Wode, Henriksson, Sharp, Stoltenberg, \& Hök Nordberg, 2019; Wortmann et al., 2016; Yalcin, Hurmuz, McQuinn, \& Naing, 2018; Şahin \& Şahin, 2013). Regardless of the chosen practices, most patients who are unaware of the potential health risks refrain from informing physicians on their use of CAM. Therefore, CAM use among patients has become a major concern of oncologists responsible for determining the optimal medical management and needs to act in time if any hazardous situation arises (Wode et al., 2019).

Although research on CAM practices, their efficacy, effects, and risks on patients with various diseases (Hakkoymaz \& Koçyiğit, 2019; Şahin \& Şahin, 2013), and malignant tumors in general (Abuelgasim et al., 2018; Bauml et al., 2015; Berretta et al., 2017; Demir \& Erol, 2018; Gözüm et al., 2003; Lopez et al., 2019; Risberg et al., 2003; Tas et al., 2005; Wode et al., 2019; Wortmann et al., 2016; Yalcin et al., 2018) is accumulating, data on CAM use among patients with HM are scarce (Can et al., 2009; Gan et al., 2015; Hensel et al., 2009; Hierl et al., 2017; Karacan et al., 2012; Molassiotis et al., 2005; Rausch Osian et al., 2015; Tazi et al., 2013).

The multi-faceted differences, such as the characteristics of participants and methodology among studies result in inconsistent and ambiguous data, and, thus, potentially impact the much-needed information on CAM use among patients. In this study, we aim to assess the CAM use in a group of Turkish hematologic malignancy patients by a multi-parameter approach and to determine the demographic and clinical factors associated with its use.

\section{PATIENTS and METHODS}

\subsection{Patient population}

This descriptive and cross-sectional study over a period of nine months between March 2019 and December 2019 included patients who were at least 18 years old, diagnosed as hematologic malignancies, and followed-up at the Hematology and Oncology Outpatient Clinics, Ümraniye Training and Research Hospital, Health Sciences University. The study protocol was approved by the Institutional Ethics Committee $(03 / 22 / 2019$, B.10.1.TKH.4.33.H.GP.0.01/51), and the signed informed consent forms were obtained from the 
patients who volunteered to participate. The patients, who were unable to cooperate and communicate due to illiteracy, language barriers, or inadequate cognitive skills, were excluded. The research was carried out in accordance with the principles of the Declaration of Helsinki.

\subsection{Study protocol and data collection}

The study was conducted in a comfortable setting in the outpatient clinics of the hospital by an experienced hematologist, who interviewed eligible patients, administered the questionnaires, explained unclear questions when required, and cross-checked the medical charts for the accuracy of clinical information provided by the participant. The attitudes of patients towards CAM were assessed by Holistic Complementary, and Alternative Medicine Questionnaire (HCAMQ) previously designed and translated to Turkish (Erci, 2007; Hyland, Lewith, \& Westoby, 2003). The lower scores obtained in HCAMQ represented positive attitudes towards CAM. The second questionnaire based on literature and adapted for the purposes of the current study consisted of eleven multiple-choice questions that assessed the demographics, clinical characteristics, and CAM-related specifics of the study population. The demographics consisted of age, gender, and education, while clinical data involved the type of hematologic malignancy diagnosed according to 2016 WHO classification (Swerdlow et al., 2016), comorbidity presence, chemotherapy use, and ECOG performance score as previously presented (Oken et al., 1982). The ECOG performance score indicates the physical condition and capabilities of the patient and ranges from 0 to 5; the lower the score, the better the physical condition. The participants were asked about CAM use, and the positive responders were further interviewed with questions that included CAM practice (timing of CAM use by the chemotherapy application, the type of phytotherapeutic agent when relevant), the source of information for CAM use, and the perceived effect of CAM.

\section{Statistical Analysis}

The statistical analyses were performed by using the "Jamovi project (2020), Jamovi (Version 1.1.9.0) [Computer Software, retrieved from https://www.jamovi.org], p-value of $<0.05$ was considered statistically significant. Descriptive statistics for continuous variables was expressed as mean \pm SD and ranged between median and quartiles. Categorical data were expressed as number and percentage. Normality for numerical variables was assessed using the Kolmogorov Smirnov test. Differences between independent groups were determined by using Independent Samples t-test and Mann Whitney U test according to normal distribution. One-Way ANOVA test was used to compare multiple independent groups with normally distributed numericals. Categorical variables were compared by using Pearson Chi-Square, Fisher's Exact, and Fisher Freeman Halton test.

\section{RESULTS}

The study was completed with 351 eligible patients with a mean age of $61.2 \pm 13.8$ years. The number of female patients (n:178, 50.7\%) was more than that of the males (n:173, 49.3\%). The results showed that most of the patients (n:214, $61 \%)$ graduated from elementary school. The diagnoses coded according to the 2016 WHO classification were then simplified into two risk categories as "high risk/malignant" and "low risk/premalignant" conditions. The former group included acute myeloid leukemia (AML), multiple myeloma (MM), hairy cell leukemia (HCL), chronic myeloid leukemia (CML), and lymphoid dysplasias (LD), which consisted of chronic lymphocytic leukemia, non-Hodgkin lymphoma, and Hodgkin lymphoma, while the latter group comprised of myelodysplastic syndrome (MDS) and myeloproliferative neoplasias (MPN) that included polycythemia vera, essential thrombocytosis and primary myelofibrosis. The most common diagnosis in our study group was lymphoid dysplasias in 151 patients $(43 \%)$, and the least represented diagnosis was hairy cell leukemia in eight patients $(2.3 \%)$. We found that comorbid 
Journal of Integrative and Anatolian Medicine

Bütünleyici ve Anadolu Tibbı Dergisi
Cilt/ Volume: 2 Sayı / Issue: 3

Yil/Year: 2021
Yayıncı / Publisher

Sağllk Bilimleri Üniversitesi University of Health Sciences conditions were present in 220 of the patients (62.7\%). The number of patients who underwent chemotherapy was 243 (69.2\%). The evaluation of the ECOG performance score of patients revealed a mean value of 1 (range: 1-2). The demographic and clinical data are presented in Table 1.

Table 1. Demographic and clinical data.

\begin{tabular}{|c|c|c|}
\hline DEMOGRAPHICS & & 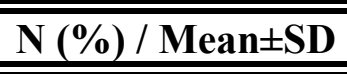 \\
\hline Age & & $61.2 \pm 13.8$ \\
\hline \multirow[t]{2}{*}{ Gender } & Male & $173(49.3)$ \\
\hline & Female & $178(50.7)$ \\
\hline \multirow{3}{*}{ Education } & $\begin{array}{l}\text { Elementary } \\
\text { Middle school }\end{array}$ & $\begin{array}{l}214(61) \\
84(23.9)\end{array}$ \\
\hline & High school & $41(11.7)$ \\
\hline & College & $12(3.4)$ \\
\hline CLINICAL & & $\mathbf{N}(\%) /$ Mean \pm SD \\
\hline \multirow{2}{*}{ Comorbidity } & Present & $220(62.7)$ \\
\hline & Absent & $131(37.3)$ \\
\hline \multirow{2}{*}{ Chemotherapy } & Yes & $243(69.2)$ \\
\hline & No & $108(30.8)$ \\
\hline ECOG Score & & $1[1-2]$ \\
\hline \multicolumn{3}{|l|}{ Diagnosis } \\
\hline High risk/malignant & & $264(75)$ \\
\hline AML & & $14(4)$ \\
\hline CML & & $30(8.5)$ \\
\hline LD & & $151(43)$ \\
\hline MM & & $61(17.4)$ \\
\hline HCL & & $8(2.3)$ \\
\hline Low risk/premalignant & & $87(25)$ \\
\hline MDS & & $24(6.8)$ \\
\hline MPN & & $63(18)$ \\
\hline
\end{tabular}

ECOG: Eastern Cooperative Oncology Group, AML: Acute myeloid leukemia, CML: Chronic myeloid leukemia, LD: Lymphoid dysplasias, MM: Multiple myeloma, HCL: Hairy-cell leukemia, MDS: Myelodysplastic syndrome, MPN: Myeloproliferative neoplasias

The mean HCAMQ score of the study group was found as $31.1 \pm 4.5$, and the statistical analysis for comparing the CAM users and non-users revealed that the mean HCAMQ score of the former group (29.6 \pm 3.6$)$ was significantly lower than that of the latter group $(34.7 \pm 4.4)(\mathrm{p}<0.001)$. Two hundred and forty-six patients $(70.1 \%)$ declared using at least one method of CAM. The majority of CAM users (n:104, 42.3\%) indicated "family/friends" as the source of information. All patients reported the use of CAM following the chemotherapy protocols. The rate of patients who perceived a positive effect of CAM was $54.9 \%$, while a negative effect was perceived by $21.5 \%$ of the patients. The most common method in our study group was phytotherapy among $65 \%$ of the CAM users, and Curcuma longa was the most commonly (n:79, 49.4\%) used phytotherapeutic agent. Table 2 shows data regarding CAM use, practices, and the list of phytotherapeutics observed in the study. 
Journal of Integrative and Anatolian Medicine

Bütünleyici ve Anadolu Tıbbı Dergisi
Cilt/ Volume: 2 Sayı / Issue: 3 Yil/Year: 2021
Yayınci / Publisher Sağllk Bilimleri Üniversitesi University of Health Sciences

Table 2. CAM-related data.

\begin{tabular}{|c|c|}
\hline & $\mathbf{N}(\%) /$ Mean \pm SD \\
\hline \multicolumn{2}{|l|}{ CAM Use } \\
\hline Yes & $246(70.1)$ \\
\hline No & $105(29.9)$ \\
\hline HCAMQ Score & $31.1 \pm 4.5$ \\
\hline \multicolumn{2}{|l|}{ Source of Information } \\
\hline Religious & $45(18.3)$ \\
\hline Family/Friends & $104(42.3)$ \\
\hline TV-Newspaper & $66(26.8)$ \\
\hline Social Media & $31(12.6)$ \\
\hline \multicolumn{2}{|l|}{ Perceived effect } \\
\hline$\overline{\text { None }}$ & $\overline{58(23.6)}$ \\
\hline Positive & $135(54.9)$ \\
\hline Negative & $53(21.5)$ \\
\hline \multicolumn{2}{|l|}{ Practice } \\
\hline Acupuncture & $10(4.1)$ \\
\hline Apitherapy & $22(8.9)$ \\
\hline Bioenergy & $3(1.2)$ \\
\hline Hijama & $58(23.6)$ \\
\hline Larvae therapy & $6(2.4)$ \\
\hline Leech therapy & $20(8.1)$ \\
\hline Ozone therapy & $29(11.8)$ \\
\hline Spiritual activity & $86(35)$ \\
\hline Vitamin/Mineral supplements & $108(43.9)$ \\
\hline Phytotherapy & $160(65)$ \\
\hline Urtica dioica & $71(44.4)$ \\
\hline Curcuma longa & $79(49.4)$ \\
\hline Nigella sativa & $57(35.6)$ \\
\hline Allium sativum & $22(13.8)$ \\
\hline Ganoderma lucidum & $40(25)$ \\
\hline Panax ginseng & $35(21.9)$ \\
\hline Hypericum perforatum & $35(21.9)$ \\
\hline Gingko biloba & $22(13.8)$ \\
\hline Ceratonia siliqua & $36(22.5)$ \\
\hline Salvia officinalis & $13(8.1)$ \\
\hline Miscellaneous & $33(20.6)$ \\
\hline
\end{tabular}

CAM: Complementary Alternative Medicine, HCAMQ: Holistic Complementary and Alternative Medicine Questionnaire 
Journal of Integrative and Anatolian Medicine

Bütünleyici ve Anadolu Tıbbı Dergisi
Cilt/ Volume: 2 Sayı / Issue: 3

Yil/Year: 2021
Yayınc1 / Publisher Sağlk Bilimleri Üniversitesi University of Health Sciences
The analyses of the relationships between CAM use and the demographic and clinical variables showed that the mean ECOG performance score of CAM users was significantly lower $(1.15 \pm 0.93)$ compared to that of the non-users $(1.39 \pm 0.94)$ ( $\mathrm{p}: 0.016)$.

The detailed analyses of each CAM method represented in our study were performed for investigating their relationships with demographic variables. We found that there was a significant association between the use of ozone therapy and a higher mean age of patients $(65.3 \pm 11)$ when compared to that of the non-users $(59.7 \pm 14.2)$ (p: 0.042). Among the users of hijama, the rate of elementary school graduates (n:41; 29.1\%) was significantly higher than the rates of middle school (n:14, 22.2\%), high school $(\mathrm{n}: 2,6.5 \%)$, and college graduates (n:1, 9.1\%) (p:0.003).

The evaluation of the relationships between CAM methods and clinical data revealed that the rate of Urtica Dioica use was significantly lower in the patients with comorbid conditions $(36 \%)$ compared to the patients without comorbidity $(64 \%)$ (p: 0.006). We found that the rate of
Allium Sativum use was significantly higher in the patients who underwent chemotherapy (17.8\%) compared to the ones who did not (5.7\%) (p:0.037). The rates of Leech therapy and hijama use were significantly lower in the patients who underwent chemotherapy $(4.2 \%$ and $13.8 \%$, respectively) compared to the ones who did not (95.8\% and $86.2 \%)$ (p:0.001; $\mathrm{p}<0.001)$. The rate of social media as the source of information was significantly higher than that of the other sources for phytotherapy users in general $(83.9 \%$, p:0.016) and specifically for Nigella sativa (53.8\%, p:0.007) and Gingko biloba (26.9\%, p:0.026) users. For the users of Curcuma longa, the rate of $\mathrm{TV} /$ newspaper use as the source of information $(66.7 \%$, p:0.018) was significantly higher than that of other sources. When we investigated the mean ECOG performance scores of CAM users and the non-users, we observed that ozone therapy users had significantly higher ECOG scores than the non-users of this practice (p:0.038) (Figure 1). The users of Nigella sativa had significantly lower mean ECOG scores compared to the non-users of this phytotherapeutic agent (p:0.006) (Figure 1).

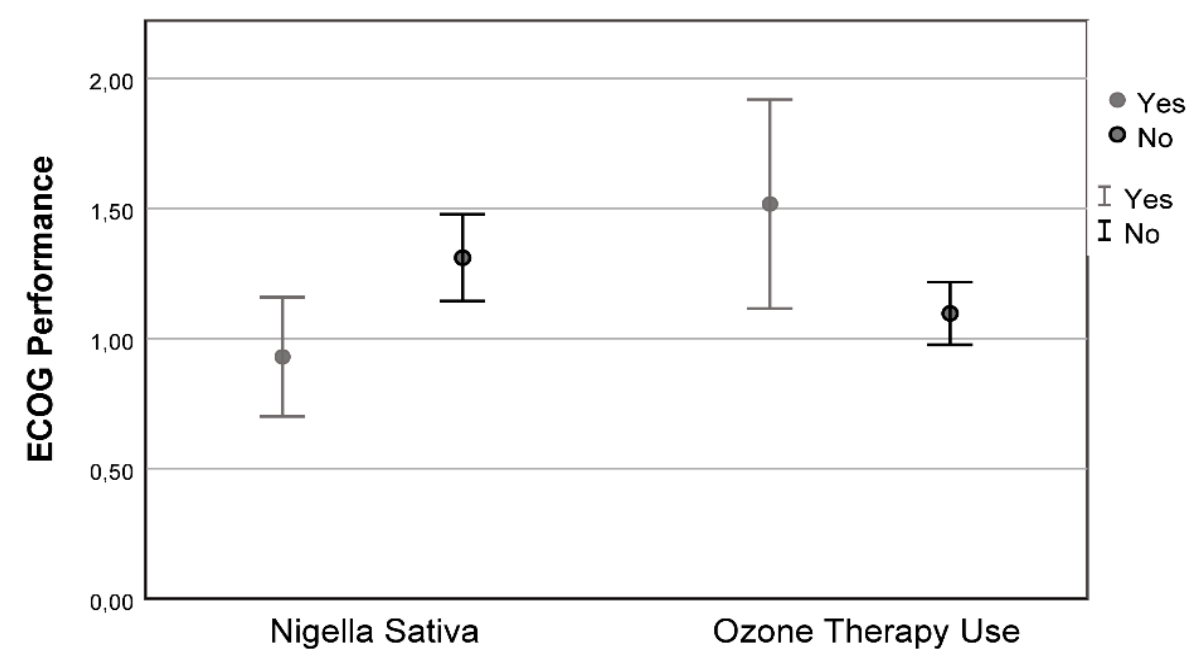

Error Bars: $95 \% \mathrm{Cl}$

Figure 1. Relationships among ECOG performance score, Ozone therapy and Nigella sativa use. 
Journal of Integrative and Anatolian Medicine

Bütünleyici ve Anadolu Tıbbı Dergisi
Cilt/ Volume: 2 Sayı / Issue: 3 Yl1/Year: 2021
Yayınc / Publisher Sağlk Bilimleri Üniversitesi University of Health Sciences
The determination of the relationships between the diagnoses and CAM practices indicated that the rate of apitherapy use $(20 \%)$ was significantly higher among AML patients (p:0.047) while the rates of leech therapy (22\%) and hijama $(60 \%)$ were significantly higher among MPN patients $(p<0.001)$. When we compared high vs. low-risk groups, we found that the rates of apitherapy $(11.8 \%, \mathrm{p}: 0.011)$ and spiritual activity (39.3\%, p:0.020) were significantly higher in the high risk/malignant group of patients while the rates of leech therapy $(16.2 \%, \mathrm{p}: 0.004)$ and hijama $(45.6 \%, \mathrm{p}<0.001)$ were significantly higher in the low risk/premalignant group of patients. Tables 3 and 4 indicate the associations between CAM methods and diagnoses in patients.

Table 3. Relationships between high- and low-risk hematologic malignancies and CAM-related data.

\begin{tabular}{|c|c|c|c|}
\hline & \multicolumn{2}{|l|}{ Diagnosis } & \multirow[b]{2}{*}{$\mathbf{P}$} \\
\hline & $\begin{array}{l}\text { High risk/ } \\
\text { malignant }\end{array}$ & $\begin{array}{l}\text { Low risk/ } \\
\text { premalignant }\end{array}$ & \\
\hline CAM & $178(67.4)$ & $68(78.2)$ & $0.058^{*}$ \\
\hline Phytotherapy & $111(62.4)$ & $49(72.1)$ & $0.154 *$ \\
\hline Apitherapy & $21(11.8)$ & $1(1.5)$ & $0.011 *$ \\
\hline Leech therapy & $9(5.1)$ & $11(16.2)$ & $0.004 *$ \\
\hline Ozone therapy & $24(13.5)$ & $5(7.4)$ & $0.182 *$ \\
\hline Spiritual activity/prayer & $70(39.3)$ & $16(23.5)$ & $0.020 *$ \\
\hline Hijama & $27(15.2)$ & $31(45.6)$ & $<0.001 *$ \\
\hline Vitamins/mineral supplements & $83(46.6)$ & $25(36.8)$ & $0.163 *$ \\
\hline \multicolumn{4}{|l|}{ Phytotherapeutic agents } \\
\hline Urtica dioica & $51(45.9)$ & $20(40.8)$ & $0.547^{*}$ \\
\hline Curcuma longa & $57(51.4)$ & $22(44.9)$ & $0.452 *$ \\
\hline Nigella sativa & $36(32.4)$ & $21(42.9)$ & $0.204 *$ \\
\hline Allium sativum & $18(16.2)$ & $4(8.2)$ & $0.173 *$ \\
\hline Ganoderma lucidum & $28(25.2)$ & $12(24.5)$ & $0.921 *$ \\
\hline Panax ginseng & $21(18.9)$ & $14(28.6)$ & $0.173^{*}$ \\
\hline Hypericum perforatum & $26(23.4)$ & $9(18.4)$ & $0.476^{*}$ \\
\hline Gingko biloba & $15(13.5)$ & $7(14.3)$ & $0.896^{*}$ \\
\hline Ceratonia siliqua & $23(20.7)$ & $13(26.5)$ & $0.417 *$ \\
\hline Salvia officinalis & $8(7.2)$ & $5(10.2)$ & $0.539 * *$ \\
\hline Miscellaneous & $24(21.6)$ & $9(18.4)$ & $0.639 *$ \\
\hline \multicolumn{4}{|l|}{ Source of information } \\
\hline Religious & $34(19.1)$ & $11(16.2)$ & \multirow{4}{*}{$0.765^{*}$} \\
\hline Family/Friends & $72(40.4)$ & $32(47.1)$ & \\
\hline Social media & $22(12.4)$ & $9(13.2)$ & \\
\hline TV/Newspaper & $50(28.1)$ & $16(23.5)$ & \\
\hline HCAMQ Score & $31.3 \pm 4.6$ & $30.7 \pm 4.1$ & $0.258 * * *$ \\
\hline
\end{tabular}

CAM: Complementary Alternative Medicine, HCAMQ: Holistic Complementary and Alternative Medicine Questionnaire 
Journal of Integrative and Anatolian Medicine

Bütünleyici ve Anadolu Tıbbı Dergisi
Cilt/ Volume: 2 Sayı / Issue: 3

Yli/Year: 2021
Yayınc1 / Publisher

Sağllk Bilimleri Üniversitesi University of Health Sciences

Table 4. Relationships between high- and low-risk hematologic malignancies and CAM-related data. Diagnosis

\begin{tabular}{lccc}
\cline { 2 - 3 } & $\begin{array}{c}\text { High risk/ } \\
\text { malignant }\end{array}$ & $\begin{array}{c}\text { Low risk/ } \\
\text { premalignant }\end{array}$ & P \\
\hline CAM & $178(67.4)$ & $68(78.2)$ & $0.058^{*}$ \\
Phytotherapy & $11(62.4)$ & $49(72.1)$ & $0.154^{*}$ \\
Apitherapy & $21(11.8)$ & $1(1.5)$ & $\mathbf{0 . 0 1 1 ^ { * }}$ \\
Leech therapy & $9(5.1)$ & $11(16.2)$ & $\mathbf{0 . 0 0 4 *}$ \\
Ozone therapy & $24(13.5)$ & $5(7.4)$ & $0.182^{*}$ \\
Spiritual activity/prayer & $70(39.3)$ & $16(23.5)$ & $\mathbf{0 . 0 2 0 ^ { * }}$ \\
Hijama & $27(15.2)$ & $31(45.6)$ & $<\mathbf{0 . 0 0 1 *}$ \\
Vitamins/Mineral supplements & $83(46.6)$ & $25(36.8)$ & $0.163^{*}$ \\
\hline Phytotherapeutic agents & & & \\
Urtica dioica & $51(45.9)$ & $20(40.8)$ & $0.547^{*}$ \\
Curcuma longa & $57(51.4)$ & $22(44.9)$ & $0.452^{*}$ \\
Nigella sativa & $36(32.4)$ & $21(42.9)$ & $0.204^{*}$ \\
Allium sativum & $18(16.2)$ & $4(8.2)$ & $0.173^{*}$ \\
Ganoderma lucidum & $28(25.2)$ & $12(24.5)$ & $0.921^{*}$ \\
Panax ginseng & $21(18.9)$ & $14(28.6)$ & $0.173^{*}$ \\
Hypericum perforatum & $26(23.4)$ & $9(18.4)$ & $0.476^{*}$ \\
Gingko biloba & $15(13.5)$ & $7(14.3)$ & $0.896^{*}$ \\
Ceratonia siliqua & $23(20.7)$ & $13(26.5)$ & $0.417^{*}$ \\
Salvia officinalis & $8(7.2)$ & $5(10.2)$ & $0.539^{* *}$ \\
Miscellaneous & $24(21.6)$ & $9(18.4)$ & $0.639^{*}$ \\
\hline CAM: Complementy Alternative
\end{tabular}

CAM: Complementary Alternative Medicine

\section{DISCUSSION}

In the current study, we investigated CAM use in a group of Turkish patients with HM by using a multi-parameter approach and determined the frequency of use and the preferred CAM practices as well as the relationships among CAM, demographics, and the clinical characteristics of the studied patient group. We found that $71 \%$ of the participants practiced CAM. In two previous studies, the rate of CAM use in chronic lymphocytic leukemia patients was $16.5 \%$ and $44 \%$ (D'Arena et al., 2014; Hensel et al., 2009). While Hierl et al. reported a frequency of $30 \%$, the results from two other studies were $70.2 \%$ and $89 \%$ (Gan et al., 2015; Hierl et al., 2017; Rausch Osian et al., 2015). A comprehensive research study covering data from 14 European countries reported the frequency of CAM use as $26.5 \%$ (Molassiotis et al., 2005). The frequency from a Moroccon study on HM patients was $68 \%$ (Tazi et al., 2013). The rates obtained from two Turkish studies, which were $71.2 \%$ and $71.5 \%$, were very close to the frequency we observed in the current study (71\%) (Can et al., 2009; Karacan et al., 2012). We found an interesting result from a study that reported significantly lower rates of CAM use in HM patients, particularly in the patients with a diagnosis of malignant lymphoma (p:0.02) (Tas et al., 2005). The broad range of CAM use frequency reported for $\mathrm{HM}$ patients might reflect the differences in the sociocultural, economic, and geographic background of the studied populations as well as the methodological nuances among studies.

Many researchers were interested in delineating a specific portrait for the CAM user; thus, almost all studies on CAM collected data on 
Journal of Integrative and Anatolian

Medicine

Bütünleyici ve Anadolu Tıbbı Dergisi
Cilt/ Volume: 2 Sayı / Issue: 3 Yll/Year: 2021
Yayncs / Publisher

Sağllk Bilimleri Üniversitesi University of Health Sciences the demographics of the studied population (Bauml et al., 2015). Female gender, younger age, and higher education were the most common demographic triad that was significant for CAM use in patients with various cancer types (Abuelgasim et al., 2018; Bauml et al., 2015; Berretta et al., 2017; Hakkoymaz \& Koçyiğit, 2019; Tas et al., 2005; Wode et al., 2019; Wortmann et al., 2016; Yalcin et al., 2018) and also for HM patients (D'Arena et al., 2014). In some studies, not the whole but parts of the triad were found to have significant relationships with the use of CAM. For example, Hensel et al. associated being 60 years or older with CAM use, while two other studies associated it with being female (Can et al., 2009; Hensel et al., 2009; Rausch Osian et al., 2015). On the contrary, no such significant associations were found in other studies on HM patients (Gan et al., 2015; Karacan et al., 2012; Molassiotis et al., 2005), or on patients with miscellaneous cancers (Demir \& Erol, 2018; Gözüm et al., 2003; Lopez et al., 2019; Risberg et al., 2003). Our results were compatible with the studies that did not report any significant demographic factors related to the use of CAM. Although it seems tempting to draw a profile for a CAM user for practical purposes, it is nearly infeasible given the non-standardized research methodology and the heterogeneity of demographics and the clinical characteristics among the studied populations. Nevertheless, it may be commented that the basis of female dominance related to CAM use found in some studies could be due to gender differences in terms of communication skills, whether verbal or written. Additionally, the other parts of the triad, which were the younger age and the higher education level, could interrelatedly act as the facilitator factors for an easier access to the technology-related sources of information, i.e., internet and various CAM practices, i.e., phytotherapeutics, mind-body practices like yoga and meditation.

When we questioned the practices of CAM used by our responders, we found that most of them were practicing multiple CAM methods concurrently. The same pattern of concurrent use was reported in other studies (Abuelgasim et al., 2018; Hakkoymaz \& Koçyiğit, 2019; Kwon et al., 2019; Molassiotis et al., 2005; Wode et al., 2019). Although we noticed that the preference of CAM practices was highly dependent on the geographic and cultural characteristics of the study population, we might safely conclude that vitamin/mineral supplementation, phytotherapy, and spiritual activity/prayer were the most common CAM practices reported in a vast amount of studies on HM patients (Can et al., 2009; D'Arena et al., 2014; Gan et al., 2015; Hensel et al., 2009; Hierl et al., 2017; Karacan et al., 2012; Molassiotis et al., 2005; Rausch Osian et al., 2015; Tazi et al., 2013). We found consistent results with the previous literature, as phytotherapy, vitamin supplementation, and prayer were practiced by $65 \%, 43.9 \%$, and $35 \%$ of the study participants, respectively. Another CAM that was frequently practiced in our study was hijama (23.6\%), aka wet cupping, is a commonly used CAM practice in specific regions of the world (Abuelgasim et al., 2018; Mazhar Uddin, Haq, \& Sheikh, 2016). In a recent study conducted on ER patients in Turkey, the authors reported a frequency of $24.2 \%$ of hijama use, while another study on CAM use in Turkey also reported high rates of hijama use (Hakkoymaz \& Koçyiğit, 2019; Şimşek et al., 2017). The authors considered the cultural and religious background in Turkey as the main cause of higher hijama rates (Şimşek et al., 2017). The same suggestion was also made for the leech and larvae therapy that were extremely rare in the Western World, despite being commonly used in our geography (Şimşek et al., 2017). In our study, we observed the rates of leech and larvae therapy use as $8.1 \%$ and $2.4 \%$, respectively. Among the most common CAM practices in our study was also spiritual activity/prayer in $35 \%$ of the participants. In two other Turkish studies, the rates of prayer among patients were found as high as $99 \%$ and $41 \%$ (Demir \& Erol, 2018; Yalcin et al., 2018). In a study on HM patients from Malaysia, high rates of prayer $(79 \%)$ were reported (Gan et al., 2015). Apitherapy was one of the most practiced CAM in our study, with a 
Cilt/ Volume: 2 Sayı / Issue: 3

Yil/Year: 2021
Yayncs / Publisher

Sağllk Bilimleri Üniversitesi University of Health Sciences frequency of $8.9 \%$. Osian et al. reported the frequency of apitherapy as $<5 \%$ in their study on NHL patients (Rausch Osian et al., 2015). In another study, the use of honey combined with other herbals was reported in a single chronic lymphocytic leukemia patient (D'Arena et al., 2014). A higher rate of $32 \%$ was reported by a Moroccan study (Tazi et al., 2013). In a previous Turkish study, $49.7 \%$ of the patients reported using apitherapy (Can et al., 2009). A Turkish study on CAM use among COPD patients found the frequency of apitherapy as $43.3 \%$ (Şahin \& Şahin, 2013). Two other Turkish studies found that patients used honey to mix it with Urtica Dioica (Gözüm et al., 2003; Tas et al., 2005).

When we analyzed the relationships between various CAM practices and diagnoses, we found that the use of spiritual activity/prayer was significantly associated with high-risk/malignant conditions (p:0.020). In a previous comprehensive study, a significant relationship between the use of religious practices and the diagnosis of lymphoma was found (p:0.04) (Can et al., 2009). Yalcin et al., who found a significantly high rate $(99 \%)$ of prayer in their study population and reported similar rates of prayer from various studies, suggested that it was a very common CAM especially practiced by patients with advanced cancer (Yalcin et al., 2018). Consistently, Gan et al. found that the rates of spiritual activity/prayer were significantly higher among the patients who received chemotherapy (Gan et al., 2015). We also found a significant relationship between the use of hijama and leech therapy and a diagnosis of MPN $(p<0.001$ and $p: 0.035$, respectively). Regarding the high- vs. low-risk HM groups in our study, we found that both hijama $(p<0.001)$ and leech therapy (p:0.004) were significantly higher in the low risk/premalignant group. The most common conventional treatment modality in our study was chemotherapy with a rate of $69.2 \%$, and we observed that both the rates of hijama and leech therapy were significantly lower in the patients who underwent chemotherapy $(p<0.001)$. It was reported that some CAM users would practice when they were free of chemotherapy or would prefer to pause CAM practices if they felt unsure about the interactions (Arthur et al., 2012). The analyses in our study revealed that the rate of hijama use was significantly higher in the graduates of elementary school (p:0.033). Thus, a likely profile for a hijama user might be drawn from our study as a patient with low-risk/premalignant condition who graduated from elementary school and who did not receive chemotherapy. The use of ozone therapy for CAM is controversial, as there are data showing adverse, even dangerous effects of ozone on human organism (Elvis \& Ekta, 2011). However, there are studies that have indicated its use as a CAM practice though in low rates $(0.4 \%)$ and $(4 \%)$ (Hakkoymaz \& Koçyiğit, 2019; Hierl et al., 2017). The rate of ozone therapy in our study was found as high as $11.8 \%$, and we found a significant association between its use and older age (p:0.042). Apitherapy was significantly higher in patients with AML in our study (p:0.047), and its use had a significant relationship with the high-risk/malignant group of patients ( $p: 0.011)$. None of the studies that reported some form of apitherapy did not indicate any significant relationships between its practice and any other parameters.

When the phytotherapeutic agents were further evaluated, we found that ten types of herbs were used with the frequencies ranging from $8 \%$ to $50 \%$. The highest-rated herbs were Curcuma longa (49.4\%), Urtica dioica (44.4\%), and Nigella sativa (35.6\%). In Hierl's study, Curcuma longa was used by $4 \%$ of the patients while just one patient used it in another study (D'Arena et al., 2014; Hierl et al., 2017). A higher rate of Curcuma longa (30\%) use was reported in a Moroccon study (Tazi et al., 2013). Can et al. found $11.7 \%$ of the patients used Curcuma longa, while a rate of $2 \%$ was reported by Molassiotis et al. (Can et al., 2009; Molassiotis et al., 2005). In two of the earlier studies on CAM practices among cancer patients from Turkey, the researchers observed exclusively high rates of Urtica dioica (93\% and $88 \%$ and $69 \%$ ) in their study population, while we observed a lower rate (44.4\%) (Gözüm et al., 2003; Karacan et al., 
Journal of Integrative and Anatolian

Medicine

Bütünleyici ve Anadolu Tıbbı Dergisi
Cilt/ Volume: 2 Sayı / Issue: 3 Yil/Year: 2021
Yayıncı / Publisher

Sağllk Bilimleri Üniversitesi University of Health Sciences
2012; Tas et al., 2005). In the present study, we observed the post-chemotherapy use of the phytotherapeutic agents as for Urtica dioica. The authors suggested that the high rates of herbal use in their study might be due to easy access, being perceived as natural, and frequent supports by media sources (Karacan et al., 2012). Nigella sativa was found as one of the most commonly used CAM phytotherapeutics in a study from Morocco and a study from Saudi Arabia (Abuelgasim et al., 2018; Tazi et al., 2013). A previous study from Turkey presented various phytotherapeutics used for CAM, where the rates of Urtica Dioica and Nigella sativa use were found as $21.2 \%$ and $11.2 \%$, respectively (Can et al., 2009). The differences of frequency for the use of various phytotherapeutics might have multiple causes; it is highly likely that the ease of accessibility due to geographic, i.e., regional flora and economic reasons can primarily be responsible from this variation. For example, Mistletoe use has been observed as one of the most common phytotherapeutic in studies from Europe, while we have not met any study mentioning its use in our region (Hensel et al., 2009). In our study, $62.7 \%$ of the patients had comorbid conditions, and we observed a significant relationship between the use of Urtica Dioica and the presence of comorbidity in our patients (p:0.006). This relationship might be due to the onset of its use prior to the malignancy and for the comorbid condition, as this herb has long been known for its anti-inflammatory, antinociceptive, and anti-diabetic effects (Hajhashemi \& Klooshani, 2013; Tas et al., 2005). Another significant relationship we observed in the current study was the higher rates of use of Allium Sativum in the patients who underwent chemotherapy (p:0.037). Although the rate of Allium Sativum use was reported as 14\% in a study on NHL, the authors did not find any significant relationship between its use and any other variables investigated in that study (Rausch Osian et al., 2015).

Although phytotherapy is generally perceived as safe and many herbs, seeds, and plant-derived agents are commonly used in
CAM, the interactions between them and conventional medicines in addition to the undelineated mechanisms of effect still continue to be one of the biggest concerns for physicians. In a very recent case report, severe bone marrow hypoplasia due to Nigella sativa ingestion was described as such an example of a dangerous effect of a phytotherapeutic agent commonly used for CAM (Narlı Özdemir, Öztürk, Kuzu, \& Özcan, 2019). An increased risk of bleeding secondary use of several phytotherapeutic agents, including Curcuma longa, Ginkgo biloba, and Nigella sativa, has been reported (Ben-Arye, et al., 2016). Interactions of herbal constituents, specifically consumed as multi-herbal formulations, may result in either synergistic or antagonistic effects on the efficacy and toxicity of each component (Enioutina, et al., 2017). Although recent publications investigating the interactions between several phytotherapeutic agents are usually related to Traditional Chinese Medicine formulations, there is little information about the possible herb-herb interactions (Singh, Gupta \& Saraf, 2012). So, it should be kept in mind that prospective studies are needed to evaluate herb-herb interactions. In a recent review, the authors reported the results of several studies on Curcuma longa and Nigella sativa. They mentioned the curcumin's powerful chemopreventive and anticancer properties by exerting anti-inflammatory, antiangiogenic and antiproliferative activities on various cancer types while they emphasized the strong antioxidant and anti-inflammatory properties of Nigella sativa (Frenkel \& Sapire, 2017). In a recent review, modest supplementation with $1000 \mathrm{mg}$ elemental calcium carbonate and $400 \mathrm{IU}$ vitamin D3 was found to reduce the risk of hematological malignancies in older women. Additionally, the anticancer potential of turmeric had been mentioned for several solid tumors as well as leukemia and lymphoma (Okolo \& Gowin, 2019). Despite the fact that the efficacy or adverse effects of phytotherapeutics in HM patients are beyond the scope of the current study, it has been interesting to observe significant associations between phytotherapy and a number 
Journal of Integrative and Anatolian Medicine

Bütünleyici ve Anadolu Tıbbı Dergisi
Cilt/ Volume: 2 Sayı / Issue: 3 Yll/Year: 2021
Yayıncı / Publisher

Sağllk Bilimleri Üniversitesi University of Health Sciences of clinical or CAM-related variables in our study. There was a significant association between the use of phytotherapy and social media as the source of information for CAM in our study (p:0.016). Similar to the rate in our study $(42 \%)$, Karacan et al. found that the major source of information (48.4\%) for phytotherapy was social media (Karacan et al., 2012). We also found that social media was significantly associated with the use of Nigella sativa (p:0.007) and Gingko biloba (p:0.026) in our study. However, no such relationships were found in the study of Tazi et al., who reported a high rate of Nigella sativa use, except the fact that they found a rate of $62 \%$ for family/friends as the sources of information for their patient group (Tazi et al., 2013). The rate of Gingko biloba use in NHL patients was reported as 7\%; however, the source of information related to its use was not reported (Rausch Osian et al., 2015). In a recent study, $67 \%$ of the CAM users declared a preference to get CAM-related information from their health providers; yet, the media and family were the top two sources in that study (Wode et al., 2019). Hierl et al. found that $24 \%$ of CAM users had friends/family as the source of information (Hierl et al., 2017). Hakkoymaz et al. found family as the primary source of information (71.6\%) (Hakkoymaz \& Koçyiğit, 2019). Another study reported the source of information for CAM user patients was $52.3 \%$ family (Gözüm et al., 2003). Friends and TV have been found to be sources of information in a recent Turkish study (Demir \& Erol, 2018). In our study, there was a significant association between Curcuma longa use and the $\mathrm{TV} /$ newspaper as the source of information (p:0.018).

Among the clinical variables investigated in our study were the ECOG performance status, current or past chemotherapy history, comorbid medical conditions, and the diagnosis of the HM patient. In the current study, the ECOG performance score of patients ranged between 1 and 2 , and the mean value was found as 1 . We found a significant relationship between CAM practice and lower ECOG score (0.016). This result was consistent with the results of a previous study that reported a significant association between lower ECOG score and CAM use (Tas et al., 2005). In another study that searched for the relationship between CAM use and ECOG performance score, no significant association was found (Demir \& Erol, 2018). The significant association between lower ECOG score and individual phytotherapeutics in the current study was found to be present for the use of Nigella sativa (p:0.006). On the other hand, we found a significant association between a high ECOG score and the use of Ozone therapy (p:0.038). It is likely conceivable from this result that there may be a threshold when the patient feels the real burden of disease on overall well-being, and this threshold may be crossed just before the patient experiences physical nuisances that correspond to ECOG performance grade 1.

The personal beliefs and attitudes about CAM were suggested to have an impact on the utilization of CAM practices in a research and were proposed to be responsible for the discrepancy of study results (Bauml et al., 2015). In our study, we assessed the attitudes of participants towards CAM by HCAMQ, and the mean score we obtained was $31.1 \pm 4.5$. This value was below the middle of the score range (11-66) and represented a positive attitude towards CA. When we compared the HCAMQ scores between CAM users and the non-users, the results showed that there was a significant difference on behalf of the users who had lower scores $(29.6 \pm 3.6)$ than the non-users $(34.7 \pm 4.4)$ as might be expected $(p<0.001)$. When we questioned the participants about the perceived effect of CAM use, we found that $54.9 \%$ of them had a positive perception. The rate of satisfaction from CAM use in our study was lower than the reported high rates in two other studies (Wode et al., 2019; Wortmann et al., 2016). A recent study from Turkey reported $18 \%$ of the patients responded positively to the question of perceived benefit from CAM use (Yalcin et al., 2018). A study from Saudi Arabia reported a high level of perceived benefits (74.3\%); however, only $7.4 \%$ of the patients who felt improvement attributed it to the CAM (Abuelgasim et al., 2018). The reason for a 
moderate level of satisfaction we observed might be expected considering the relatively low mean HCAMQ score $(29.6 \pm 3.6)$ that indicated a positive attitude towards CAM use. Thus, patients might have higher expectations for CAM to start with, and it would be harder to feel fully content when the real effects of CAM were experienced. Moreover, patients who suffer from malignant diseases have very complicated emotions, one of which is the feeling of content. A multi-layered and a well-tailored methodological approach seems to be required for an accurate assessment of the satisfaction of cancer patients with the CAM methods they use.

There are limitations to this study that need to be addressed. First, as this study was conducted in a single-center, the collected data might partially represent the population in general. The setting was the outpatient clinics of the hospital, so all patients were either actively under conventional medical therapy or on posttreatment surveillance; therefore, potential patients who denied conventional therapy and just chose to practice CAM were not included in the study. Considering the mean ECOG performance score of our patients, there might be a bias against the inclusion of advanced-stage cancer patients in the study. The strengths of our study include the cross-sectional design and the large sample size. Additionally, the methodology of the study with two separate questionnaires enabled us to evaluate multiple aspects of CAM use. We focused our research on HM patients that would predictably make the conclusions drawn more clear and specific.

\section{CONCLUSION}

Our results indicated that a high proportion of hematological malignancy patients used at least one method of CAM; and phytotherapy, especially Curcuma longa, Urtica dioica, and Nigella sativum, vitamin supplementation and spiritual activity/prayer were the most common ones. The perceived effect of CAM therapy among patients was mostly positive. While friends/family of the patients were the primary sources of information about CAM in general, we observed the influence of social media and $\mathrm{TV} /$ newspaper on the common phytotherapeutics in our study. We expect that our comprehensive research on CAM practice in HM patients will contribute to the literature and set an example for further and larger studies.

\section{REFERENCES}

Abuelgasim, K. A., Alsharhan, Y., Alenzi, T., Alhazzani, A., Ali, Y. Z., \& Jazieh, A. R. (2018). The use of complementary and alternative medicine by patients with cancer: a cross-sectional survey in Saudi Arabia. BMC Complement Altern Med, 18(1), 88. doi:10.1186/s12906-018-2150-8

Arthur, K., Belliard, J. C., Hardin, S. B., Knecht, K., Chen, C. S., \& Montgomery, S. (2012). Practices, attitudes, and beliefs associated with complementary and alternative medicine (CAM) use among cancer patients. Integr Cancer Ther, 11(3), 232-242. doi:10.1177/1534735411433832

Bauml, J. M., Chokshi, S., Schapira, M. M., Im, E. O., Li, S. Q., Langer, C. J., . . . Mao, J. J. (2015). Do attitudes and beliefs regarding complementary and alternative medicine impact its use among patients with cancer? A cross-sectional survey. Cancer, 121(14), 2431-2438. doi:10.1002/cncr.29173

Ben-Arye, E., Samuels, N., Goldstein, L.H., Mutafoglu, K., Omran, S., Schiff, E., . . . Silbermann, M. (2016). Potential risks associated with traditional herbal medicine use in cancer care: A study of Middle Eastern oncology health care professionals. Cancer, 122(4), 598-610. doi: 10.1002/cncr.29796

Berretta, M., Della Pepa, C., Tralongo, P., Fulvi, A., Martellotta, F., Lleshi, A., . . F Facchini, G. (2017). Use of Complementary and Alternative Medicine (CAM) in cancer patients: An Italian multicenter survey. Oncotarget, 8(15), 24401-24414. doi:10.18632/oncotarget.14224

Bray, F., Ferlay, J., Soerjomataram, I., Siegel, R. L., Torre, L. A., \& Jemal, A. (2018). Global cancer statistics 2018: GLOBOCAN estimates of incidence and mortality worldwide for 36 cancers in 185 countries. CA Cancer J Clin, 68(6), 394-424. doi: $10.3322 /$ caac. 21492

Can, G., Erol, O., Aydiner, A., \& Topuz, E. (2009). Quality of life and complementary and alternative medicine use among cancer patients in Turkey. 
Journal of Integrative and Anatolian Medicine

Bütünleyici ve Anadolu Tibbı Dergisi
Cilt/ Volume: 2 Sayı / Issue: 3 Yil/Year: 2021
Yayınc1 / Publisher

Sağllk Bilimleri Üniversitesi University of Health Sciences
Eur J Oncol Nurs, 13(4), doi:10.1016/j.ejon.2009.03.007

D'Arena, G., Laurenti, L., Coscia, M., Cortelezzi, A., Chiarenza, A., Pozzato, G., . . . De Feo, V. (2014). Complementary and alternative medicine use in patients with chronic lymphocytic leukemia: an Italian multicentric survey. Leuk Lymphoma, 55(4),

841-847.

doi:10.3109/10428194.2013.803223

Demir, B. D., \& Erol, O. (2018). Complementary and Alternative Medicine Use among Turkish Cancer Patients and the Influencing Factors. Int J Caring Sci, 11(1), 319-332.

Elvis, A. M., \& Ekta, J. S. (2011). Ozone therapy: A clinical review. J Nat Sci Biol Med, 2(1), 66-70. doi:10.4103/0976-9668.82319

Enioutina, E.Y., Salis, E.R., Job, K.M., Gubarev, M.I., Krepkova, L.V. \& Sherwin, C.M. (2017). Herbal Medicines: challenges in the modern world. Part 5. status and current directions of complementary and alternative herbal medicine worldwide. Expert Rev Clin Pharmacol, 10(3), 327-338. doi: 10.1080/17512433.2017.1268917

Erci, B. (2007). Attitudes towards holistic complementary and alternative medicine: a sample of healthy people in Turkey. J Clin Nurs, 16(4), 761-768. doi:10.1111/j.1365-2702.2006.01655.x

Frenkel, M., \& Sapire, K. (2017). Complementary and Integrative Medicine in Hematologic Malignancies: Questions and Challenges. Curr Oncol Rep, 19(12), 79. doi:10.1007/s11912-0170635-0

Gan, G. G., Leong, Y. C., Bee, P. C., Chin, E., \& Teh, A. K. (2015). Complementary and alternative medicine use in patients with hematological cancers in Malaysia. Support Care Cancer, 23(8), 2399-2406. doi:10.1007/s00520-015-2614-z

Gözüm, S., Tezel, A., \& Koc, M. (2003). Complementary alternative treatments used by patients with cancer in eastern Turkey. Cancer Nurs, 26(3), 230-236. doi:10.1097/00002820-200306000-00010

Hajhashemi, V., \& Klooshani, V. (2013). Antinociceptive and anti-inflammatory effects of Urtica dioica leaf extract in animal models. Avicenna J Phytomed, 3(2), 193-200.
Hakkoymaz, H., \& Koçyiğit, B. F. (2019). Assessment of complementary and alternative medicine use among patients admitted to the emergency room: a descriptive study from a Turkish hospital. PeerJ, 7, e7584. doi: 10.7717 peerj.7584

Hensel, M., Zoz, M., \& Ho, A. D. (2009). Complementary and alternative medicine in patients with chronic lymphocytic leukemia. Support Care Cancer, 17(1), 47-52. doi:10.1007/s00520-008-0452-y

Hierl, M., Pfirstinger, J., Andreesen, R., Holler, E., Mayer, S., Wolff, D., \& Vogelhuber, M. (2017). Complementary and Alternative Medicine: A Clinical Study in 1,016 Hematology/Oncology Patients. Oncology, 93(3), 157-163. doi:10.1159/000464248

Hyland, M. E., Lewith, G. T., \& Westoby, C. (2003). Developing a measure of attitudes: the holistic complementary and alternative medicine questionnaire. Complement Ther Med, 11(1), 3338. doi:10.1016/s0965-2299(02)00113-9

Karacan, Y., Akkuş, Y., Akdemir, N., Göker, H., Salih, A., Sucak, G. A., . . . Ali, R. (2012). Kök hücre nakli hastalarında tamamlayıcı ve alternatif tedavi kullanımı. Uludağ Üniversitesi Tip Fakültesi Dergisi, 38(1), 1-6.

Kwon, J. H., Lee, S. C., Lee, M. A., Kim, Y. J., Kang, J. H., Kim, J. Y., . . . Rha, S. Y. (2019). Behaviors and Attitudes toward the Use of Complementary and Alternative Medicine among Korean Cancer Patients. Cancer Res Treat, 51(3), 851-860. doi:10.4143/crt.2019.137

Lopez, G., Salas, C. A., Cadiz, F., Barriga, C., Gonzalez, P., Acevedo, S., . . . Quiroga, M. (2019). Complementary and Integrative Medicine Use in Individuals Seeking Conventional Medical Oncology Care in Chile: Prevalence and Patient Characteristics. $J$ Glob Oncol, 5, 1-6. doi:10.1200/jgo.18.00190

Mazhar Uddin, S. M., Haq, A., \& Sheikh, H. (2016). The Use of Hijama (Wet Cupping) in Alternative and Complementary Medicine: Efficacious or Perilous? J Acupunct Meridian Stud, 9(6), 285286. doi:10.1016/j.jams.2016.09.002

Molassiotis, A., Margulies, A., Fernandez-Ortega, P., Pud, D., Panteli, V., Bruyns, I., . . . Patiraki, E. (2005). Complementary and alternative medicine use in patients with haematological malignancies in 
Journal of Integrative and Anatolian Medicine

Bütünleyici ve Anadolu Tibbı Dergisi
Cilt/ Volume: 2 Sayı / Issue: 3 Yil/Year: 2021
Yayıncı / Publisher

Sağllk Bilimleri Üniversitesi University of Health Sciences
Europe. Complement Ther Clin Pract, 11(2), 105110. doi:10.1016/j.ctcp.2004.12.005

Narlı Özdemir, Z., Öztürk, C., Kuzu, I., \& Özcan, M. (2019). Severe Bone Marrow Hypoplasia with Black Cumin (Nigella sativa) Ingestion in a Patient with T-ALL in First Complete Remission. Turk J Haematol, 36(3), 215-217. doi:10.4274/tjh.galenos.2019.2019.0093

Oken, M. M., Creech, R. H., Tormey, D. C., Horton, J., Davis, T. E., McFadden, E. T., \& Carbone, P. P. (1982). Toxicity and response criteria of the Eastern Cooperative Oncology Group. Am J Clin Oncol, 5(6), 649-655.

Okolo, O. N., \& Gowin, K. (2019). Emerging Role of Integrative Medicine in Hematologic Malignancies: a Literature Review and Update on Current Trends in Complementary Medical Practices in Hematologic Cancers. Curr Hematol Malig Rep, 14(4), 328-336. doi:10.1007/s11899019-00526-8

Rausch Osian, S., Leal, A. D., Allmer, C., Maurer, M. J., Nowakowski, G., Inwards, D. J., . . Thompson, C. A. (2015). Widespread use of complementary and alternative medicine among non-Hodgkin lymphoma survivors. Leuk Lymphoma, 56(2), 434-439. doi:10.3109/10428194.2014.916803

Risberg, T., Vickers, A., Bremnes, R. M., Wist, E. A., Kaasa, S., \& Cassileth, B. R. (2003). Does use of alternative medicine predict survival from cancer? Eur J Cancer, 39(3), 372-377. doi:10.1016/s09598049(02)00701-3

Şahin, Z. A., \& Şahin, M. (2013). The view of patients with Choronic Obstructive Pulmonary Disease (COPD) on Complementary and Alternative Medicine (CAM) in Eastern Turkey. Afr $J$ Tradit Complement Altern Med, 10(4), 116-121.

Şimşek, B., Aksoy, D. Y., Basaran, N. C., Taş, D., Albasan, D., \& Kalayc1, M. Z. (2017). Mapping traditional and complementary medicine in Turkey. European Journal of Integrative Medicine, 15, 6872.

doi:https://doi.org/10.1016/j.eujim.2017.09.006

Singh, D., Gupta, R., \& Saraf, S.A. (2012). Herbs-are they safe enough? an overview. Crit Rev Food Sci Nutr, 52(10), 876-98. $10.1080 / 10408398.2010 .512426$.
Swerdlow, S. H., Campo, E., Pileri, S. A., Harris, N. L., Stein, H., Siebert, R., . . J Jaffe, E. S. (2016). The 2016 revision of the World Health Organization classification of lymphoid neoplasms. Blood, 127(20), 2375-2390. doi:10.1182/blood-2016-01643569

Tas, F., Ustuner, Z., Can, G., Eralp, Y., Camlica, H., Basaran, M., .. . Topuz, E. (2005). The prevalence and determinants of the use of complementary and alternative medicine in adult Turkish cancer patients. Acta Oncol, 44(2), 161-167. doi:10.1080/02841860510007549

Tazi, I., Nafil, H., Sifesalam, M., Bouchtia, M., \& Mahmal, L. (2013). Prevalence of complementary and alternative medicine use in patients with hematological malignancies in Marrakech, Morocco. J Acupunct Meridian Stud, 6(2), 67-68. doi:10.1016/j.jams.2012.12.007

Witt, C. M., Balneaves, L. G., Cardoso, M. J., Cohen, L., Greenlee, H., Johnstone, P., . . Mao, J. J. (2017). A Comprehensive Definition for Integrative Oncology. J Natl Cancer Inst Monogr, 2017(52). doi:10.1093/jncimonographs/lgx012

Wode, K., Henriksson, R., Sharp, L., Stoltenberg, A., \& Hök Nordberg, J. (2019). Cancer patients' use of complementary and alternative medicine in Sweden: a cross-sectional study. BMC Complement Altern Med, 19(1), 62. doi:10.1186/s12906-019-2452-5

World Health Organization. (2019). WHO global report on traditional and complementary medicine. Geneva: World Health Organization.

Wortmann, J. K., Bremer, A., Eich, H. T., Wortmann, H. P., Schuster, A., Fühner, J., . . . Huebner, J. (2016). Use of complementary and alternative medicine by patients with cancer: a cross-sectional study at different points of cancer care. Med Oncol, 33(7), 78. doi:10.1007/s12032-016-0790-4

Yalcin, S., Hurmuz, P., McQuinn, L., \& Naing, A. (2018). Prevalence of Complementary Medicine Use in Patients With Cancer: A Turkish Comprehensive Cancer Center Experience. J Glob Oncol, 4, 1-6. doi:10.1200/jgo.2016.008896

Yönetmelik. T.C. Başbakanlık Mevzuatı Geliştirme ve Yayın Genel Müdürlüğü. Resmi Gazete. Retrieved from

https://www.resmigazete.gov.tr/eskiler/2014/10/2 0141027-3.htm 